\title{
CIĄGLOŚĆ CZY ZERWANIE? PRZYCZYNEK DO ROZWAŻAŃ NA TEMAT HISTORII POLSKIEJ MYŚLI SOCJALISTYCZNEJ XIX WIEKU
}

\author{
JAN KOZUBOWSKI
}

\begin{abstract}
Abstrakt: Celem artykułu jest próba obalenia utrzymywanego w historiografii podziału polskiego socjalizmu dziewiętnastowiecznego na „socjalizm naukowy” oraz „socjalizm utopijny”. Koncepcja „Idei komunistycznej” Alaina Badiou i Slavoja Žižka pozwala na uwypuklenie ciagłości w historii tego odłamu rodzimej refleksji politycznej. Rama „,wiecznej idei” została w artykule wykorzystana do porównania programu Gromad Ludu Polskiego z poglądami polskich marksistów, a także do podważenia tez historyków PRL, którzy stworzyli ideologiczna przepaść między wspomnianymi typami „socjalizmów”. Analizując podobieństwa między „romantykami” a marksistami, wyznaczam polskie „niezmienne komunistyczne”, wśród których wyróżniam wiodącą cechę polskiej myśli rewolucyjnej: pozytywnie ujmowaną utopijność. Wskazuję również, że różnice w poglądach dwóch pokoleń socjalistów były zdeterminowane społeczno-gospodarczymi okolicznościami występującymi w dwóch różnych okresach historycznych.
\end{abstract}

Słowa kluczowe: socjalizm utopijny, socjalizm naukowy, Gromady Ludu Polskiego, utopijność, marksizm, Kazimierz Kelles-Krauz 
Idee Owena, Fouriera, Kropotkina, Landauera, twórców wspólnot religijnych i swieckich stopity sie zprzekonaniami Marksa i Engelsa; stajemy sie sceptyczni wobec czysto ideologicznych sformułowań „celów ostatecznych" i bardziej nas obchodzi konkretna osoba, tu i teraz. Erich Fromm, Zdrowe Spoleczeństwo $(2017,308)$

W niniejszym artykule staram się udowodnić ciąłłość ideologiczna pomiędzy poszczególnymi etapami rozwoju polskiej myśli socjalistycznej dziewiętnastego wieku. Zamiast ujmować narodziny polskiego marksizmu w kategoriach „cięcia epistemologicznego”, przedstawiam je jako wynik ewolucji polskiej myśli społecznej. Idąc za przykładem Bolesława Limanowskiego, za socjalizm uznaję dziewiętnastowieczną formę Idei komunistycznej, która narodziła się wraz z kapitalizmem (Limanowski 1948, 144). Jej rozwój przypada więc na okres „długiego wieku dziewiętnastego", który dzielę w celach metodologicznych na dwa bloki: 1) okres Wielkiej Emigracji - powstanie Gromad Ludu Polskiego, czyli pierwszego ugrupowania socjalistycznego, które według Marksowskiej wykładni hołduje „socjalizmowi utopijnemu”; 2) okres rozwoju masowego ruchu politycznego - marksizm do 1918 roku. Porównując polityczno-społeczne koncepcje socjalistyczne powstałe w dwóch wymienionych okresach, wyodrębniam z nich te najważniejsze idee, które przez przeszło sto lat towarzyszyły polskiemu ruchowi socjalistycznemu. Wśród nich znajduje się romantyczna utopijność, która jest podstawowym, ciagłym elementem myśli komunistycznej (jej stałą, immanentną cecha). Wiązała się ona z apoteozą czynu i była główna przyczyną nonkonformistycznych postaw społecznych (podważała kapitalistyczne status quo).

Ze względu na ogromny polityczno-filozoficzny dorobek obu pokoleń socjalistów postanowiłem kierować się następującymi kryteriami doboru materiałów źródłowych. Po pierwsze, moja intencja nie jest porównywanie dokonań ideowych pojedynczych postaci historycznych, lecz ogólne scharakteryzowanie polskiego socjalizmu. Jest to możliwe dzięki analizie idei dominujących w dyskursie danych partii politycznych. Po drugie, biorę pod uwagę tylko organizacje i nurty socjalistyczne zajmujące centralną pozycję w dwóch różnych okresach historycznych. Po trzecie, zakładam, że do wykazania ciagłości polskiego socjalizmu potrzebne jest porównanie socjalizmu romantycznego z marksizmem. Po czwarte, rozpatruję przede wszystkim koncepcje powstałe na emigracji, gdyż kluczowe dla ewolucji polskiego socjalizmu pierwszej połowy dziewiętnastego wieku było zetknięcie się emigrantów polistopadowych z ideami zachodniego socjalizmu utopijnego oraz dostrzeżenie gospodarczych zmian zachodzących w krajach centrum. Aby porównanie dwóch socjalizmów było miarodajne, w analizę włączam również emigracyjne koncepcje marksistowskie. 
Wszystkie cztery warunki spełniaja dwie organizacje polityczne: Gromady Ludu Polskiego (GLP) oraz emigracyjne struktury Polskiej Partii Socjalistycznej ${ }^{1}$. Co do dominacji GLP w latach trzydziestych dziewiętnastego wieku nie ma wątpliwości: uznaje się je za pierwszą polską partię socjalistyczną. Zakładam, że ich odezwy partyjne (będące dziełem mało licznej organizacji, która nie posiadała radykalnie różniących się odłamów) oddają charakter romantycznego socjalizmu. W przypadku emigracyjnych filii PPS - liczniejszej partii, w której istniało wiele stronnictw, trudno jest postapić tak samo jak przy analizie dyskursu Gromad. Potrzebne jest wyodrębnienie pewnych ideowych dominant należących równocześnie do „dojrzałego” marksizmu. Przyjmuję więc, że publicystyka Kazimierza Kelles-Krauza oddaje charakter „Czysto” marksistowskiego (tj. pozbawionego wschodnich - narodnickich naleciałości anarchistycznych) ducha zagranicznej części PPS. Leszek Kołakowski nazwał go „ortodoksem na modłę polską” (Kołakowski 2009, 221), bezsprzecznie włączając go w obręb konsekwentnie marksistowskiego programu politycznego. Kelles-Krauz, jako „najważniejszy ideolog późniejszego skrzydła lewicowego” (Czekaj 2008, 102), był z pewnością najwybitniejszym marksistowskim działaczem emigracyjnym. Andrzej Mencwel zaznacza, że uznaje się go również za głównego teoretyka PPS w ogóle (Mencwel 2013, 473). W niniejszej pracy jego postać, wraz z Zenonem Świętosławskim, służy za przykład emigracyjnego zaangażowanego inteligenta szlacheckiego pochodzenia.

Po przedstawieniu wstępnych założeń metodologicznych warto przejść do prezentacji współczesnej historiozofii socjalizmu, która stanowi teoretyczną oś niniejszej pracy.

\section{Wieczna idea}

Podstawę tezy o „wieczności” Idei komunistycznej stanowi koncepcja antagonistycznego postępu dziejowego. W Maniféśie Komunistycznym Karol Marks i Fryderyk Engels piszą o nim następująco:

Cała dotychczasowa historia społeczeństwa przebiegała w przeciwieństwach klasowych, przybierających w różnych okresach różne formy.

Jakiekolwiek jednak formy przybierały te przeciwieństwa, wyzysk jednej części społeczeństwa przez drugą był faktem wspólnym dla wszystkich ubiegłych stuleci. Nic więc dziwnego, że świadomość społeczna wszystkich tych stuleci, mimo całej różnorodności i odmienności, obraca się w pewnych wspólnych formach, w takich

\footnotetext{
${ }^{1}$ Najpierw Związek Zagraniczny Socjalistów Polskich (autonomiczny względem krajowej PPS), od 1900 roku integralna część PPS (Snyder 2010, 165).
} 
formach świadomości, które zanikną doszczętnie dopiero z zupełnym zniknięciem przeciwieństw klasowych (Marks i Engels 1983, 86).

Wyzyskowi, który według Marksa towarzyszył wszystkim społeczeństwom od momentu ich powstania, w teorii sformułowanej przez Alaina Badiou, a później rozwiniętej przez Slavoja Žižka przeciwstawiony jest odwieczny opór wobec dominacji klasowej. Związany był on właśnie z Ideą komunistyczną, która żyła w wystąpieniach klas podporządkowanych przeciwko klasom panującym, a historycznie różne formy tych antagonizmów klasowych determinowały różnorodność organizacyjnych i ideowych form oporu. Idea komunistyczna zawsze zawierała w sobie obietnicę zniesienia nieustającej walki. Dlatego właśnie Badiou nazywa ja „hipotezą”, a więc przypuszczeniem o możliwości zaistnienia innego (lepszego) systemu społecznoekonomicznego. Hipoteza komunistyczna zakłada, że istniejąca od czasów starożytności hierarchia klasowa nie jest koniecznością, można ją przezwyciężyć: należy przyjąć, że osiągalne jest społeczeństwo bez nierówności majątkowych, bez przymusu państwa, a nawet bez podziału pracy (Badiou 2008, 98-99). Marks tworzy więc podstawy, na których Badiou nadbudowuje swoją koncepcję:

Jako czysta Idea równości hipoteza komunistyczna bez wątpienia występowała w praktyce od początków istnienia aparatu państwowego. Gdy tylko masowe akcje zaczynają przeciwstawiać się państwowemu przymusowi w imię egalitarnej sprawiedliwości, pojawiają się zaczątki lub fragmenty hipotezy komunistycznej. [...] Popularne rewolty takie jak powstanie niewolników dowodzonych przez Spartakusa lub niemieckich chłopów wiedzionych przez Thomasa Müntzera są przykładami występowania w praktyce komunistycznych niezmiennych (Badiou 2008, 100).

Jak wskazuje powyższy cytat, siła Idei opiera się na sprzeciwie, walce z aparatem represji, ma więc przede wszystkim negatywny charakter. Może jednak zostać przekuta w konkretny program pozytywny: pierwszym krokiem ku temu musi być oddanie się Idei, bez czego zarówno emancypacyjna polityka, jak i zachowanie godnego ludzkiego życia w „zwierzęcym” kapitalistycznym świecie jest, według Badiou, niemożliwe² (Badiou 2010, 63-67).

Zdaniem francuskiego filozofa hipoteza komunistyczna składa się z trzech niezmiennych czynników, które tworza jej ogólne teoretyczne ramy. Po pierwsze, rewolucje przywdziewały stare formy organizacyjno-ideologiczne, co wiązało się z wykorzystaniem narzędzi klasy

\footnotetext{
${ }^{2}$ Według Badiou człowiek może być postrzegany dwojako: jako człowiek-zwierzę oraz jako człowiekpodmiot. Jest zwierzęciem ponieważ skupia się na realizacji swojego egoistycznego interesu. ,Jest śmiertelny i drapieżny" (Badiou 2009, 29). Człowiek-zwierzę staje się podmiotem (człowiekiem nieśmiertelnym), gdy „przeciwstawi się woli-bycia-zwierzęciem” (Badiou 2009, 30), odda się pewnej idei Dobra. W ramach systemu kapitalistycznego człowiek pozostaje w stanie zwierzęcym, staje się podmiotem, gdy oddaje się Idei komunistycznej.
} 
panującej do jej obalenia, w walce klasowej wykorzystana mogła być m.in. ideologia panująca czy religia (np. Müntzer usprawiedliwiał chłopską rewoltę doktryną protestantyzmu). Gromady Ludu Polskiego wykorzystywały chrześcijańskie metafory do wytłumaczenia potrzeby bezwzględnej równości. Równocześnie zasady religijne ulegały reinterpretacji, co zauważa Piotr Kuligowski, wskazując, że w percepcji GLP „[w]olność, równość i braterstwo zostały wręcz uznane za przykazania boże, które fałszywi księża dotychczas zasłaniali przed oczyma ludu" (Kuligowski 2012, 56).

Po drugie, hipoteza zawiera pewną historycznie niezmienną treść. „Od Spartakusa do Mao” jest artykulacją aksjomatów, które autor nazywa „komunistycznymi niezmiennymi”. Nie są one z góry przypisane określonej klasie. W historii różne grupy uciskanych przejmowały rolę dziejowego rewolucjonisty: niewolnicy, chłopi, proletariusze. Niezmienny był za to antagonizm między masami a państwem:

\begin{abstract}
Nasza hipoteza zakłada, że wszystkie wielkie rewolty klas wyzyskiwanych (niewolników, chłopów, proletariuszy) znajdowały swoją ideologiczna ekspresję w egalitarnych, antywłasnościowych oraz antypaństwowych hasłach, które zarysowuja podstawowe cechy komunistycznego programu (cyt. za: Bosteels, 2011, 277-278).
\end{abstract}

Za najważniejsze niezmienne tej Idei Badiou uznaje „równościową sprawiedliwość”, „woluntaryzm”, „terror” oraz „wiarę w lud” (Žižek 2008, 417-418).

Po trzecie, Idea musi zostać historycznie zrelatywizowana. Konieczne jest, aby zawierała w sobie jakieś novum: każdy system społeczno-ekonomiczny może obdarzyć rewolucyjną możnością inną klasę społeczną, a ta, żeby spełnić swoje dziejowe posłannictwo, musi oddać się „odwiecznej” Idei, jednocześnie uaktualniając ustalenia wcześniejszych rewolt komunistycznych (np. absolutyzując swoje dokonania, stawiając mur między „socjalizmem utopijnym” a „naukowym”) (Bosteels 2011, 277-278). Schemat tej relatywizacji rozwinął Žižek, zauważając że „postęp rewolucyjny polega nie tyle na stopniowym postępie, ile na powtarzającym się ruchu, ruchu powtarzania początku po raz kolejny i kolejny” (Žižek 2011a, 148). Można powiedzieć, że Idea komunistyczna jest za każdym razem ponownie wynaleziona. Nie jest wieczna w takim sensie, że zawsze materializuje się w tej samej postaci, musi być modyfikowana zgodnie $\mathrm{z}$ duchem momentu historycznego i wynikać z rzeczywistych antagonizmów istniejących w danej epoce (Žižek 2011a, 149).

Ta ostatnia cecha Idei pozwala na rozpatrywanie jej historii w kategoriach postępu czy raczej „rewolucyjnego postępu”. Według Badiou w politycznych dziejach świata możliwe jest wyróżnienie konkretnych etapów rozwoju Idei komunistycznej: hipoteza przybrała współczesna postać w czasach Rewolucji Francuskiej. Ukształtowały się wtedy jej główne założenia teoretyczne i praktyczne, na które złożyły się koncepcje zarówno socjalistów „utopijnych”, jak i marksistów (Badiou 2008, 97-98). „Postępowy skok”, który rozpoczą tę 
fazę, wiąże się z postacią Gracchusa Babeufa. Jego zasługi trafnie opisał Zygmunt Bauman. Według autora rozprawy Socjalizm: Utopia w driałaniu Babeuf dokonał syntezy dorobku dwóch dotychczas odrębnych nurtów społecznych - połączył tradycje komunizmu ,jako abstrakcyjnej zasady moralnej czy nakazu rozumu, dziedzictwa Platona, Morusa i Campanelli oraz plebejska tradycję buntu przeciwko niesprawiedliwości sięgającą wstecz do inicjatyw starorzymskich braci [Gracchus - przyp. JK] [...]” (Bauman 2010, 47). W ten sposób ukształtowała się nowoczesna postać Idei komunistycznej - socjalizm. Połączono praktykę rewolucyjną z teoretycznofilozoficzną krytyką stanu istniejącego.

Ciąłość między dwoma etapami polskiej historii socjalizmu wynika przede wszystkim z faktu, że zarówno socjaliści polistopadowi, jak i marksiści dziewiętnastowieczni należą do współczesnej fazy hipotezy komunistycznej, która zaczyna się wraz z wystapieniem Babeufa. Inny pogląd na tę sprawę miała jednak duża część historyków PRL-u.

\section{Dyskusje historyków}

W Manifeście Komunistycznym Marks i Engels przeprowadzili podział na „socjalizm utopijny” oraz „socjalizm naukowy”. „Utopiści” mieli charakteryzować się tworzeniem oderwanych od rzeczywistości wizji idealnego ustroju i nie zdawać sobie sprawy z historycznie doniosłej roli proletariatu, który traktowali tylko jako część cierpiących mas (Marks i Engels 1983, 101).

Marksowskie rozróżnienie było kultywowane w polskiej historiografii po drugiej wojnie światowej. W 1955 roku Hanna Temkinowa w nawiązaniu do pism Lenina ${ }^{3}$ tłumaczyła „utopijność polskich gromadzian, wskazując, że nie zdawali sobie sprawy ze „ścieżki rozwoju” historii. Chcieli uchronić Polskę przed nadejściem kapitalizmu, nie rozumiejąc, że dopiero z niego wyłoni się komunizm. Z tego wynikała sprzeczność między subiektywnymi dążeniami przedstawicieli ludu i obiektywnymi skutkami tych działań (Temkinowa 1955, 46-50). Tę ortodoksyjną krytykę utopizmu kontynuował później m.in. Zygmunt Najdowski, wskazując, że „[u]topijność jest rezultatem niepełnej znajomości istotnych elementów rzeczywistości społecznej” (Najdowski 1989, 64-66). Autor porównał sformułowanie koncepcji materializmu historycznego do odkrycia medycznego, wobec czego utopijność byłaby leczeniem choroby przed odkryciem odpowiedniego leku. Do grona dwóch wyżej wymienionych historyków zaliczyć można również Irenę Koberdowa, która zaznaczała, że „socjaliści utopijni” nie chcieli doprowadzić do ukształtowania się proletariatu, czyli jedynej siły w historii mogącej zbudować komunizm. W związku z tym, że chłopi, do których zwracały się Gromady Ludu Polskiego, nie mieli rozwiniętej świadomości klasowej, socjalizm agrarny musiał odwoływać się do mistyki, religii czy moralności (Koberdowa 1977, 18-19). Historyczka podkreślała, że Gromady można

\footnotetext{
${ }^{3}$ Historyczka cytuje m.in. artykuł Socjalizm a chłopstwo Lenina (1985, 260-268).
} 
nazwać organizacją socjalistyczną tylko dlatego, że krytykowały nadchodzący kapitalizm (Koberdowa 1989, 9). Autorka nie zauważyła, że członkowie pierwszej polskiej organizacji socjalistycznej uważali się za kontynuatorów wielowiekowej walki, która ciągnęła się od czasów starożytnych plebejuszy po czasy ukraińskich i litewskich chłopów. Wyrażały podstawowa cechę Idei komunistycznej - przeciwstawiały się jakiejkolwiek niesprawiedliwości społecznej, krytykowały i feudalizm, i kapitalizm, stanowiły więc stadium rozwoju Idei, która nie jest tylko i wyłącznie wynikiem istnienia kapitalizmu. Jest za to wynikiem „wiecznej” walki klasowej. Z kolei religijne zabarwienie myśli Gromad (drugi zarzut Koberdowej) było determinowane okolicznościami historycznymi, w jakich organizacja ta się rozwijała - stały za tym czasy romantyzmu (podążając tym tokiem rozumowania można zauważyć, że marksizm końca dziewiętnastego wieku charakteryzował się zabarwieniem pozytywistycznym).

Romantyczny mistycyzm był odpowiedzią na potrzebę nowego wyrażenia komunistycznej utopii, a więc formą aktualizacji Idei. Według Briana Portera-Szűcsa politycznie ujmowany romantyzm wiązał się z apoteozą uczuciowo motywowanego czynu, dzięki któremu można było znaleźć się w określonej wspólnocie (np. narodowej) (Porter-Szűcs 2011, 27-28). To zjawisko nie uszło uwadze Limanowskiego, który wiąże uczuciowość socjalizmu z religijną retoryką polityczną (Limanowski 1948, 145). Są one cechami dyskursu Gromad Ludu Polskiego, które zdominowały charakter organizacji po zmianach personalnych w jej szeregach. Po opuszczeniu organizacji przez Stanisława Worcella centralna postacią stał się Świętosławski, a wraz z nim w GLP zaczęła dominować atmosfera mistycyzmu ${ }^{4}$ Kuligowski analizuje tę zmianę charakteru ideologii Gromad przez pryzmat transformacji językowej (wykorzystując kategorię Sattelzeit Reinhardta Kosellecka). Wskazuje, że zamiana języka politycznego na język święty wiąże się z kryzysem wywołanym długoletnią emigracja: „,[...] silny mistyczny komunizm Z. Świętosławskiego oraz jego oniryczne wizje [...] były odpowiedzia na pewne potrzeby byłych żołnierzy mieszkających w barakach w Portsmouth" (Kuligowski 2015, 276).

Determinujący wpływ okresu historycznego na socjalizm można również zauważyć w czasach supremacji pozytywizmu, który postawił na scjentystyczno-przyrodniczą analizę społeczeństwa. Porter-Szűcs podkreśla, że na „najbardziej podstawowym poziomie »wolę« zastapiła »nauka« i »prawo«" (Porter-Szűcs 2011, 70). Intelektualną atmosferę czasów Drugiej Międzynarodówki zdominowała koncepcja nieuchronności komunizmu oraz stadiów, które do niego prowadza. Za paradygmatyczny przykład ideologa pozytywistycznego marksizmu uznaje się najczęściej Karla Kautsky’ego (Snyder 2010, 198). Jest to oczywiście duże uogólnienie: polski socjalizm końca dziewiętnastego wieku wyróżniał się na tle europejskim, ponieważ był

\footnotetext{
${ }^{4}$ Rozróżnienie na dwa okresy historii GLP (okres Stanisława Worcella oraz okres Zenona Świętosławskiego) przeprowadzili m.in. Ciołkoszowie (1966).
} 
reakcją przeciwko krajowemu pozytywizmowi. „Pokolenie niepokornych”5, zauważając potrzebę zbrojnego wywalczenia niepodległości, doprowadziło do rehabilitacji romantycznego czynu, połączyło go jednak z pozytywistyczno-empiryczną analizą społeczeństwa (PorterSzűcs 2011, 104). Za przedstawiciela tego rewolucyjnego pokolenia z pewnością można uznać Kelles-Krauza. Należał on do grupy ideowych bojowników, „którzy mieli w sobie dziedzictwo Kościuszki, legionistów i romantyzmu polskiego” (Mencwel 2013, 470).

Adam i Lidia Ciołkoszowie byli świadomi omówionych powyżej różnic w romantycznym i pozytywistycznym episteme. Zdając sobie sprawę z nieustannie zmieniającego się ducha Idei komunistycznej oraz przeciwstawiając się ahistorycznej ocenie dokonań działaczy czasów Wielkiej Emigracji, nazwali ich system filozoficzny „socjalizmem romantycznym” (A. Ciołkosz i L. Ciołkosz 1966, 12). Nie akceptowali teleologicznego myślenia historyków krajowych, którzy spoglądali na socjalizm z obiektywistycznego stanowiska jakoby zakończonego procesu historycznego. Materializm dialektyczny z perspektywy „wiecznej idei” był jej aktualizacja zgodną z duchem czasu - ponownym „wynalezieniem” komunizmu. Rozróżnienie Marksa i jego następców, wbrew ich intencjom, traktuję relatywistycznie. Marksizm pojawił się w odpowiedzi na nowopowstałe, obiektywne okoliczności - kapitalizm w jego wczesnej formie, którą Michael Burawoy nazywa rynkowym despotyzmem (Burawoy 1985).

\section{Powstanie}

Wspomniana wyżej „aktualizacja” Idei, w określonych warunkach historycznych jest sama w sobie rewolucyjna i stanowi ideowy postęp w stosunku do wcześniejszych etapów rozwoju. Ten dialektyczny rozwój trafnie opisał Fredric Jameson:

[...] najbardziej wiarygodny sprawdzian polityczny tekstów utopijnych wiąże się nie tyle z oceną poszczególnych dzieł, ile przede wszystkim z ich zdolnością do wytwarzania dzieł nowych, nowych utopijnych wizji zawierających wszystkie poprzednie a zarazem korygujących je i modyfikujących (Jameson 2011, XVI).

Taki proces miał miejsce w czasach Wielkiej Emigracji i wiązał się z powstaniem Gromad Ludu Polskiego. Same narodziny tego ugrupowania miały zabarwienie rewolucyjne. Oddawały negatywny charakter Idei komunistycznej, były bowiem oporem wobec decyzji zaborców: w wyniku buntu na statku, który pierwotnie miał płynać za ocean, żołnierze powstania listopadowego zaokrętowali w Portsmouth (Kalembka 2003, 24). Wkrótce zorganizowali się w sekcję Towarzystwa Demokratycznego Polskiego (TDP), której charakter klasowy

\footnotetext{
5 Bohdan Cywiński nazwał tak pokolenie wychowane w czasach pozytywizmu, a działające politycznie na przełomie wieków (zob. Cywiński 2010).
} 
z pewnościa uznać można za ludowy ${ }^{6}$. Wiązało się to z konfliktami między radykalizująca się sekcja a Centralizacją TDP. Za objaw tej radykalizacji można uznać zapewnienie, że poglądy członków sekcji opierają się „na dobrze zgłębionym pojęciu socjalizmu” (Okólniki 1834-1836, 154). Według Lidii i Adama Ciołkoszów żołnierze z Portsmouth w piśmie do Centralizacji pierwszy raz w historii Polski użyli słowa „socjalizm”. Autorzy Zarysu driejów socjalizmu polskiego wskazują że najprawdopodobniej wyraz ten został przejęty z myśli francuskich socjalistów, przypuszczalnie od Étienne’a Cabeta - francuski utopista przebywał w Anglii od 1835 roku i utrzymywał bliskie kontakty z emigrantami polskimi (A. Ciołkosz i L. Ciołkosz 1966, 72). Poglądy członków sekcji zostały ukształtowane przez pisma największych radykałów ówczesnego wieku, które były im dostarczane przez inteligentów z wyspy Jersey. Czytali m.in. Saint-Juste'a, Buonarrotiego czy Babeufa. Za ludową apoteozą pracy oraz nienawiścia do próżniactwa stały zapewne pisma Saint-Simona (A. Ciołkosz i L. Ciołkosz 1966, 117). Z kolei religijne zabarwienie argumentacji politycznej wiąże się najprawdopodobniej z lekturami pism Lammenaisa oraz Bucheza (Sikora 1974, 67; A. Ciołkosz i L. Ciołkosz 1966, 117). Dzięki połączeniu tych wszystkich idei oraz zaaplikowaniu ich do warunków polskich powstał program wspólnej własności ziemi, który okazał się punktem zapalnym między sekcją Portsmouth a Centralizacja. Do uzasadnienia tego radykalnego postulatu żołnierze wykorzystali francusko-oświeceniową koncepcję prawa natury, która w deklaracji Praw Człowieka i Obywatela pełniła m.in. funkcję legitymizująca istnienie własności prywatnej (A. Ciołkosz i L. Ciołkosz1966, 74): „Każdy człowiek rodzi się z prawem do życia, do egzystencji [...]" (Okólniki 1834-1836, 186). Według gromadzian prawo własności jest sprzeczne z prawem do życia, powstało dzięki „rozbojowi, grabieży” (A. Ciołkosz i L. Ciołkosz 1966), odwiecznemu wyzyskowi. Odpowiedź Centralizacji TDP na taki program nie jest jednoznaczna, ale zawiera w sobie tradycyjną krytykę socjalizmu:

\begin{abstract}
Wstrzymujemy się również od uwag nad teorią o równości bezwzględnej i wspólności majątkowej, przekonani, że ta jako ułamek wspólny wszystkim (począwszy od Minosa i Platona, aż do Babeufa i szkoły St. Simońskiej) utopistom doktryny, nie znajdzie w Tow. sympatji (Okólniki 1834-1836, 191).
\end{abstract}

Powyższa wypowiedź wskazuje na ideologiczne inspiracje żołnierzy-socjalistów, które z jednej strony zachowują ciagłość refleksji utopijnej (odwołanie do dokonań Platona), z drugiej dowodzą aktualizacji Idei komunistycznej (nawiązanie do współczesnych socjalistów

\footnotetext{
${ }^{6}$ Według Krzysztofa Marchlewicza „,większość członków tej sekcji wywodziła się z kręgów warszawskiego rzemiosła i proletariatu lub całe dorosłe życie spędziła w wojsku" (Marchlewicz 2008, 92-93). Sławomir Kalembka wskazuje, że „Gromada Grudziąż była bardziej organizacją plebejsko-żołnierską niż chłopską” (Kalembka 2003, 171-172).
} 
francuskich). Przywołany cytat udowadnia również, że rozłam w strukturze TDP był nieunikniony: w 1835 roku grupa żołnierzy rozpoczęła suwerenny byt jako Gromada Grudziąż.

W politycznym usamodzielnieniu się grupy żołnierzy z Portsmouth dużą rolę odegrali inteligenci znajdujący się na wyspie Jersey. Trzech z nich można uznać za głównych twórców ideologii Gromad Ludu Polskiego: Stanisława Worcella, Tadeusza Krępowieckiego i Zenona Świętosławskiego (Limanowski 1948, 134, 201). Wkrótce po opuszczeniu TDP założyli oni Gromadę Humań, która podporządkowała się Grudziążowi. Stanisław Szpotański zaznacza, że „[n]aturą filozoficzną był Worcell, marzycielską Świętosławski” (Szpotański 1907, 44). Trzeci z założycieli GLP, Krępowiecki (wcześniej jeden z twórców TDP), odróżniał się charakterem rewolucyjnym. Według Limanowskiego wyrażana przez niego nienawiść do szlachty oraz gotowość do walki klasowej wynikały z jego mieszczańskiego rodowodu (Limanowski 1948, 202; Szpotański 1907, 43). Worcell - przeciwnie do Krępowieckiego - był mniej bezkompromisowy, nad zemsta przeważało w nim „apostolstwo idei socjalnej” (Limanowski 1948, 202). W związku z ogromnym filozoficznym i organizacyjnym wkładem Worcella w organizacji, Ciołkoszowie nazywaja go „pierwszym polskim działaczem socjalistycznym" (A. Ciołkosz i L. Ciołkosz1966, 104).

Tak oto z połączenia pierwiastka inteligenckiego i ludowego powstała pierwsza polska organizacja socjalistyczna (Kalembka 2003, 171; Kuligowski 2015, 270). Od razu nasuwa się skojarzenie ze strukturą klasową partii hołdujących zasadom „,socjalizmu naukowego”: warstwa zaangażowanej inteligencji (spauperyzowanej szlachty) tworzyła ideowy człon partyjnych zarządów (np. w PPS). Znakomitym przykładem takiego inteligenta-ideologa jest postać Kazimierza Kelles-Krauza, który pochodził z rodziny barońskiej.

Powstanie GLP dowodzi, że system hierarchii klasowej w Polsce i na emigracji nie mógł podporządkować sobie wszystkich klas społecznych: „Idea komunistyczna jest wieczna potrzebą właściwą temu elementowi, który nie posiada odpowiedniego miejsca w hierarchii społecznej (»jesteśmy niczym, a chcemy być wszystkim«)" (Žižek 2011b). Elementem zaburzającym porządek społeczny byli z pewnością buntujący się żołnierze. Ich organizacja Gromada - udowadniała istnienie rozwiniętej świadomości klasowej podmiotu rewolucyjnego, czyli ludu. Sam lud, gdy zrozumie pierwotną wykładnię nauk Chrystusa, które według Gromad były wyrazem „idei socjalnej” (ponownego połączenia się we wspólnotę), będzie swoim własnym wyzwolicielem. Niezbędne jest do tego stopienie się inteligencji z ludem, co miało pozwolić na krzewienie wśród niego zasad socjalistycznych. Dlatego właśnie, jak wskazuje Kuligowski, Gromady nie uważały się za „przyjaciół ludu”, ale za sam lud (Kuligowski 2015, 271). W historii polskiej lewicy zapoczątkowały tym samym specyficzną relację między zaangażowaną politycznie elitą ruchu a klasą uciskaną. Ta ciągłość objawia się między innymi w podobnym definiowaniu podmiotu rewolucyjnego w myśli marksistowskiej: agitacja miała doprowadzić do powstania zorganizowanego przez samych proletariuszy, własnoręcznego 
„zrzucenia kajdan”. Program pierwszej polskiej partii marksistowskiej, Proletariatu, zakładał, że „wyzwolenie klasy pracującej spod ekonomicznego, polityczno-socjalnego i moralnego ucisku powinno być dziełem samych robotników" (Odezwa Komitetu Robotniczego Soc. Rew. „Proletariat”1975, 197).

Gromadzką wizję zlania się z ludem można zobrazować na przykładzie biografii Zenona Świętosławskiego, z pochodzenia szlachcica. ,Ja sam zrodzony spośród nich [szlachty - przyp. JK], widywałem ich, bywałem pośród nich i nawet kochałem ich [...]” (cyt. za: Brock 1958, 64-65). Służbę na rzecz ludu traktował jako formę zadośćuczynienia za wieki wyzysku, które chłopstwu zafundowała jego klasa społeczna. Otwarcie pisze, że Lud Polski „zbyt sowicie tak mnie jak rodzinie i przodkom moim płacił, abym myślał, że się kiedykolwiek z długu mojego w całości uiszczę choćbym do zgonu mojego niezmordowanie dla niego pracował" (Świętosławski 1854, 356). Według Petera Brocka Świętosławski, jako szlachcic współtworzący etos inteligencki, może być uznany za prekursora rosyjskich narodników oraz ludowych ruchów w Europie Wschodniej. Podobnie jak późniejsi narodnicy doprowadził on do syntezy tradycji regionalnej, narodowej (dziedzictwo katolickiej Polski) z oświeceniowym dorobkiem Rewolucji Francuskiej i zachodniego socjalizmu (Brock 1954, 587).

Charakterystyczne dla polskiej odmiany Idei było deklarowane przez intelektualistów podporządkowanie się ludowi. W ich percepcji klasa wyzyskiwana „była niczym”, a więc nie miała nic do stracenia, co oznacza, że tylko ona mogła zaryzykować zmianę całego ładu społecznego. Gdy tylko klasa ta posunie się do sformułowania niepokornej myśli („chce być wszystkim”), przestanie „być niczym”, a zdobędzie siłę, by „ruszyć z posad bryłę świata” stanie się mesjaszem ludzkości. Idea komunistyczna zamieniała słabość podporządkowanych w ich zbiorowa potęgę, co działo się niezależnie od momentu historycznego. W Manifestach dla filozofii Badiou analizuje przytoczone wyżej słowa Międsynarodówki przez pryzmat swojej koncepcji egzystencji politycznej. Francuski filozof przeprowadza rozróżnienie między bytem a egzystencją: Marks w swoich pismach dowodził bytu proletariatu, który istnieje „empirycznie” (ekonomiczno-socjologicznie). Jednakże w związku ze swoją „polityczną mnogością” proletariat nie uwidacznia się w sferze politycznej, nie ma reprezentacji, nie egzystuje. Manifestuje się to w słowach śpiewanych przez wyzyskiwanych: ,,jesteśmy niczym”. Stawanie się „wszystkim” zakłada zmianę porządku społecznego, czyli zmianę transcendentalnego. „Transcendentalne musi się zmienić, żeby wezwanie do egzystencji zmieniło kolejność i dotyczyło nieistniejącego, czyli punktu niepojawiania się w mnogości” (Badiou 2015, 148). Zamiana w podmiot jest więc działaniem rewolucyjnym. Następowała w różnych okolicznościach historycznych i to o nich traktuje następny rozdział tego artykułu. 


\section{Ziemia a kapitał}

Idea komunistyczna aktualizowała się w kontrze do obiektywnych stosunków gospodarczych występujących na ziemiach polskich (interpretowanych w kontekście zmian gospodarczych zachodzących w krajach emigracyjnych). Według Tadeusza Łepkowskiego polski skok przemysłowy obejmuje mniej więcej lata 1830-1890 (Lepkowski 1967, 86-87), a więc czasy działalności socjalistów polistopadowych oraz marksistów końca dziewiętnastego wieku.

Chociaż przemiany kapitalistyczne rozpoczęły się w pierwszym analizowanym okresie historii socjalizmu (po powstaniu listopadowym), to dopiero w przypadku drugiego okresu (koniec dziewiętnastego wieku) można mówić o faktycznej „władzy kapitału nad praca””. Uzasadnione jest więc przyporządkowanie tym dwóm okresom myśli socjalistycznej dwóch różnych etapów rozwoju gospodarczego. Za Johnem K. Galbraithem przyjmuję, że w okresach tych panowała hegemonia dwóch różnych czynników produkcji. W okresie agrarnego feudalizmu, przeciwko któremu występowali pierwsi socjaliści dziewiętnastego wieku, ziemia była czynnikiem zapewniającym panowanie klasowe, a władzę dzierżyli posiadacze ziemscy. W drugim okresie posiadanie kapitału było podstawą stratyfikacji społecznej (Galbraith 1973, 173-175). Uogólniając, można stwierdzić, że pierwsi nowocześni socjaliści sprzeciwiali się przede wszystkim wykluczeniu ludu wiejskiego pozbawionego ziemi, podczas gdy marksiści domagali się oswobodzenia tych, którzy nie posiadali kapitału.

Pomimo tych różnic ważną okolicznością łączącą oba okresy była ciągłość stosunków gospodarczych - tereny polskie pozostawały przede wszystkim obszarami rolniczymi. Problem chłopstwa i wsi był problemem uniwersalnym, którego marksiści nie mogli zignorować (Tych 1982a, 24). Faktem jest jednak, że w drugiej połowie dziewiętnastego wieku nastąpiła przyspieszona industrializacja, dzięki której Królestwo Polskie stało się jednym z najbardziej rozwiniętych regionów Imperium Rosyjskiego. W polskiej rewolucji przemysłowej ważną rolę odegrała część bogatego ziemiaństwa oraz zaborczy aparat państwowy. Nastąpiła dyfuzja władzy z ziemi do kapitału: obszarnicy inwestowali w rodzący się przemysł, co pozwalało na zdobycie kapitału, a tym samym na utrzymanie władzy (Kula 1983, 67-69). Następowała przy tym doniosła zmiana kulturowa, zaczął rodzić się polski duch kapitalizmu. Według Jana Sowy w czasach zależności feudalnej szlachta nie traktowała kapitału jako środka produkcji (gotowy do zainwestowania i przynoszenia zysków), ale jako środek konsumpcji (Sowa 2011, 120-121). Łączyło się to z magnacką rozrzutnością i przepychem, który kontrastował z coraz intensywniejszą eksploatacja mas. To właśnie takim drastycznym nierównościom przeciwstawiali się socjaliści polistopadowi. Ich zdaniem szlachta swoim egoistycznym zachowaniem zaprzedała Polskę zaborcom. Walka z uciskiem społecznym wiązała się więc z walką o wyzwolenie polityczne. 
Socjaliści wiedzieli jednak, że czasy się zmieniają. Mieli przeczucie nadejścia epoki protestanckiej, gromadzenia kapitału już nie po prostu po to, by go wydać na konsumpcję, ale żeby go pomnożyć. W akumulacji coraz przydatniejsze stawały się rządowe zlecenia, cła państwowe i protekcja. Państwo zaborcze strzegło interesów fabrykantów i często przychodziło im z pomocą podczas strajków. W takich warunkach narodził się polski marksizm i tak jak w przypadku socjalistów pierwszej połowy dziewiętnastego wieku, walka o wyzwolenie socjalne była równocześnie walką z caratem. I w czasach popowstaniowych, i pod koniec dziewiętnastego wieku walczono z państwem (Tych 1982a, 21).

\section{Feudalizm i kapitalizm}

Zgodnie z wykładnią Badiou i Žižka komunizm był ideą-ruchem, który przez tysiąclecia podważał zastane nierówności społeczne i dążył do utopijnego zrealizowania „królestwa wolności” czy „królestwa bożego” na ziemi. Przyczyny oraz poziom owych nierówności zmieniały się przez wieki. W związku z pewną ciąłłością okoliczności gospodarczych na dziewiętnastowiecznych ziemiach polskich zarówno socjalizm polistopadowy, jak i marksizm krytykowały struktury feudalne oraz kapitalistyczne. W ramach krytyki kapitalizmu objawiła się jednak zasadnicza różnica pomiędzy oboma nurtami. W percepcji marksistów kapitalizm był nieuniknionym stadium historii, dla gromadzian był zaś zaprzeczeniem postępu.

Krytyka istniejącego systemu społecznego wynikała z przeprowadzenia analizy klasowej, która nie pozwalała na przedstawienie harmonijnej wizji przeszłości Polski. W okresie Wielkiej Emigracji pojawiła się ważna dla dziejów całego późniejszego socjalizmu idea antagonistycznych „ojczyzn”, które objawiaja się w jednym społeczeństwie. Był to podział dychotomiczny, który zakładał postępowy charakter jednej z nich:

\footnotetext{
Ojczyzna nasza, to jest lud polski zawsze była odłączona od ojczyzny szlachty, i jeżeli było jakie zetknięcie pomiędzy krajem szlachty polskiej i krajem ludu polskiego, miało ono niezaprzeczone podobieństwo styczności, jaka zachodzi pomiędzy zabójcą a ofiara. Morze krwi na całym świecie rozgranicza szlachtę od ludu (Brock 1958, 69).
}

Walka klasowa była walką hegemoniczna „ojczyzn” pracujących (ludu) oraz przywłaszczycieli (szlachty). W wyniku tych myślowych podziałów pojawiła się nowa koncepcja „ludu-narodu”, która na ponad sto lat trafiła do słownika polskiej lewicy, a przyjęta została w formie postulatu wprowadzenia „Polski Ludowej” (Kuligowski 2015, 276-277). Według Kuligowskiego Gromady „otworzyły nowy rozdział w historii Polski” (Kuligowski 2015), powołując do życia ten koncept. To dokonanie może być uznane za najlepszy dowód ciagłości idei socjalistów polskich. Świadczy o tym przyjęcie takich samych założeń przez marksistów czasów „emancypacji pierwotnej”, którzy również wskazywali, że historia to „wieczny antagonizm” 
pracy z kapitałem. Niemożliwy jest kompromis, „bo niemożebna [jest - przyp. JK] solidarność niewolnika i pana”. „Pod jednym dachem wojujące strony żyć nie będą, nic wspólnego ojczyzny jednej nie mają i mieć nie moga [...] zdradzała interesy ludu demokracja nasza [...]” (Notkowski 1978, 173-174).

Gromady Ludu Polskiego wiązały przedstawiony wyżej stan nierówności klasowych w czasach kapitalistycznych m.in. z rozwojem religijności protestanckiej, która ich zdaniem zainfekowała egoizmem Anglię oraz Stany Zjednoczone. Lud był podmiotem reprezentującym postęp, któremu na przeszkodzie stał kapitalistyczny indywidualizm. Anglia była krajem zapóźnionym, zaś Francja przodowniczką zmian społecznych (Temkinowa 1957b, 349). Skoro siły wytwórcze Anglii, przez marksistów podziwiane jako najbardziej rozwinięte na świecie, dla Gromad były wyznacznikiem zapóźnienia dziejowego, to rewolucja stanowiła jedyną szansę na zatrzymanie ekspansji ładu kapitalistycznego. Symptomatyczna była charakterystyka systemu angielskiego przedstawiona przez Świętosławskiego: „[...] panowie tutejszych tłumów! rozumni! przebiegli! wiedzą jak z niczego zrobić pieniądze! siadają i piszą tomy całe o tym że nieszczęście jest narodu kiedy mu się dużo dzieci rodzi! [...]” (Świętosławski 1854, 315). Socjaliści romantyczni w kapitalizmie widzieli zwielokrotnienie feudalnych patologii, a przede wszystkim nie godzili się na podział społeczeństwa na posiadających oraz nieposiadających, co miało miejsce w obu systemach społecznych (Temkinowa 1955, 7).

Moralny wymiar tej analizy opierał się na podstawowym antagonizmie: indywidualizm socjalizm. Gromady podkreślały, że „,...] to cośmy w nauce Chrystusa wyczerpnęli, to jest: socjalizm czyli poświęcenie” (Świętosławski 1854, 56). Ówczesny system społeczny opierał się na supremacji silnych i bezwzględnych: ,Jakto! Tyle względów dla silnych, a ani jednego słowa, ani słówka nawet dla tych co nie moga pracować!!!” (Świętosławski 1854, 56). Socjalizm dostrzegał nieszczęścia słabych, choć nie proponował wyłącznie ronienia łez nad ludzka tragedią. Jednostkowa słabość wykluczonych mogła być przekuta w siłę, jeżeli ci połączą się w jeden podmiot - lud. Oparte na Piśmie Świętym rozumienie sprawiedliwości stanowiło podstawę wiary w powodzenie dążeń rewolucyjnych. Dychotomiczny charakter tego rodzaju analiz umożliwiał Gromadom swobodne przejście od retoryki oburzenia do zapowiedzi ukarania wyzyskiwaczy. Światło miało zwyciężyć nad ciemnością, dobro nad złem, prawda nad kłamstwem. Oczywiście niezbędne do tego było uświadomienie masom ich rzeczywistego interesu klasowego: same podniosą się do walki dopiero wtedy, gdy zrozumieją, że wyzysk jest nieusprawiedliwiony, że tak jak jest, nie musi być zawsze (Świętosławski 1854, 57).

Gromady za swojego głównego przeciwnika ideologicznego uważały Towarzystwo Demokratyczne Polskie, którego program, ich zdaniem, zwiastował nadejście żywiołowego, niszczycielskiego kapitalizmu. Upadający feudalizm jawił się członkom Gromad jako mniej destrukcyjny niż rodzący się kapitalizm, który TDP miałoby wspierać postulatami indywidualnego współzawodnictwa i praw własności. „Naszymi ciałami gotowi jesteśmy zasłać 
Polskę, aby ją uwolnić od tej morowej zarazy przemysłu i handlu w takim znaczeniu wziętych, jakie mu dziś eksploatacja kupiecka nadaje” (Sikora 1974, 101). Przyczynę rozwodu z TDP zarysowano w broszurze Do emigracji polskiej. Po ideowym sukcesie, za jaki gromadzianie uważali Mały Manifest, demokraci porzucili sprawę ludu. Manifest z 1832 roku był aktem założenia TDP, który kładł silny nacisk na pierwiastki socjalistyczne. Według GLP Towarzystwo zawarło w tym dokumencie program walki o sprawę ludu, o jak najdalsze urzeczywistnienie zasady braterstwa i, co najważniejsze, o „wspólną dla wszystkich ziemię i jej owoce” (Temkinowa 1957b, 54). Jednak już w drugim manifeście demokratów z 1836 roku, który uwidaczniał polityczną ewolucję organizacji (oddalenie się od socjalizmu), zawarto postulat prywatnej ziemi i „każdej innej własności pracy” (Temkinowa 1957a, 29). Według GLP program taki miał sprawić, że ziemia „stanie się własnością bankierów” (Temkinowa 1957a,115). Tak więc kiedyś wspólnym celem było „porównanie kondycji socjalnych”, zaś teraz TDP „utrwala i sankcjonuje cierpienia ludu, obiecuje mu rzucić kawałek ziemi jak kość psu zgłodniałemu i matwaniami lelewelizmu przeładowane, wściekłościami lafajetyzmu, waszyngtonizmu opite, gotowe jest już [...] sprawę powszechna zgubić [...]" (Temkinowa 1957b, 55). Pomimo tej zajadłej krytyki gromadzianie postrzegali swój program jako konsekwentne przedłużenie wcześniejszych założeń TDP: „Myśl, cel Towarzystwa Demokratycznego [...] jest w nas, jest przy nas [...]” (Sikora 1974, 135-136). Lud był potrzebny demokratom do wywalczenia niepodległości i postulat uwłaszczenia miał go do tego zachęcić. Dla Gromad interes ludu był celem samym w sobie, cały porządek społeczny miał być konstytuowany w oparciu o jego potrzeby, których realizacje miała zapewnić rewolucja. Zwięźle scharakteryzowano ten aspekt ideologii GLP w piśmie do sekcji TDP:

Jako ludzie postępu i ruchu, to jest: zasad i rewolucji, ponieśliśmy przed Towarzystwo Demokratyczne dwa pomysły, które uważaliśmy jako pożyteczne społeczności ludzkiej: najprzód zmianę natury posiadania dóbr ziemskich jako cel przeobrażenia społecznego; użycie siły jako środek spełnienia tego celu (cyt. za: Temkinowa 1962, 41).

Wyłania się więc kolejne podobieństwo między marksistami a socjalistami romantycznymi stosunek do klasy mieszczańskiej. Marks postulował dokończenie rewolucji rozpoczętej przez burżuazję, podobnie gromadzianie chcieli kontynuować projekt porzucony przez mieszczańskie TDP. Z perspektywy socjalistów program demokratów z TDP mógł być uznany za mieszczański, gdyż opierał się na programie prywatnej własności ziemi oraz uwłaszczenia chłopów. Konsekwencja wprowadzenia w życie tych postulatów byłaby możliwość swobodnego obrotu własnościa, powstanie rynku, a w konsekwencji - ukształtowanie się systemu pracy najemnej. Socjaliści romantyczni oraz demokraci różnili się również wyborem adresatów swoich programów. Według Szymona Dyksztajna TDP zwracało się w swoich pismach do szlachty, a nie do ludu, co było głównym dowodem na klasowy charakter tej 
organizacji (Dyksztajn 1904, 72). Wiązało się to z podstawowym demokratycznym postulatem - wprowadzeniem równości wobec prawa. Zarówno marksiści, jak i gromadzianie uważali jednak, że rewolucja burżuazyjna wprowadzała wolność i równość formalną. Wartości te kłóciły się z praktyka: będąc formalnie wolnym, robotnik przy sprzedawaniu swojej pracy stawałby się niewolnikiem kapitalisty. Według Gromad stosunek demokratów do warstwy ludowej prezentuje się następująco:

Gdyby po tysiącznych zawiedzionych przyrzeczeniach $[\ldots]$ nasza szlachta, jeszcze raz na koń siadłszy, w imieniu Towarzystwa Demokratycznego powołała do powstania uciskanych przez nią chłopów, gdyby im prawić zaczęła o równości w obliczu prawa, o wolności umierania z głodu, o braterstwie pomiędzy możnym, a ubogim, wilkiem a owcą [...] nie moglibyśmy [...] zaręczyć, że pójda (Sikora 1974, 156 - podkr. $\mathrm{JK})$.

Powyższą krytykę burżuazji zauważyli pierwsi polscy marksiści, którzy byli pełni uznania dla dokonań Gromad, pomimo tego, że odcinali się od tradycji Wielkiej Emigracji. Program uspołecznienia własności zaprezentowany przez I Proletariat uznać można za rozwinięcie koncepcji Gromad. Dyksztajn w 1880 roku pisał w tym kontekście następująco:

\footnotetext{
Pośród rozmaitych szkół socjalistycznych [...] niewiele było takich, którym udało się sięgnąc do samego źródła nierówności społecznej, wyzyskiwania, nędzy mas i zbytku garstki próżniaków, przemocy mniejszości i niewoli tłumów. Polscy socjaliści sięgnęli do niego [...] uznali za jedyną radykalną i konieczną reformę zniesienie prywatnej, indywidualnej władności, zaprowadzenie własności wspólnej ziemi i fabryk. Dążenie do nowego porządku rzeczy, opartego na wspólności narzędzi pracy, stało się ich celem. Zawładnąć narzędziami pracy dla ludu - tak pojmowali oni pracę dla ojczyzny, narodowości i ludowej niepodległości (cyt. za: Notkowski 1978, 192-193).
}

Jak wykazał Dyksztajn w powyższym cytacie, sedno marksistowskiego programu, czyli wspólna własność środków produkcji, zostało wskazane już czterdzieści lat przed pojawieniem się marksizmu w Polsce. Wspomniana w cytacie rewolucyjność oraz chęć zniesienia własności prywatnej są polskimi „komunistycznymi niezmiennymi”, dzięki którym Gromady artykułowały swój sprzeciw wobec zmieniającej się rzeczywistości, dlatego też najpełniej wyrażały one uniwersalizm Idei komunistycznej. Brały pod uwagę rzeczywistość „tu i teraz”, nie skupiały się na odległych ,celach ostatecznych”. Z etycznego punktu widzenia nie ma znaczenia, czy na świecie zagości system kapitalistyczny, czy utrzyma się ład feudalny, oba są bowiem wynikiem panowania klasowego. W obu elita istnieje dzięki własności prywatnej. „,[S]łużalstwo panom tytularnym czy niewola pieniądzom: wszystko to jedno” (Sikora 1974, 142). 


\section{Rewolucja}

Rewolucja francuska powołała do życia pierwowzór nowoczesnej emancypacji społecznej, rozpoczynając tym samym współczesną fazę Idei komunistycznej. Gromady, odwołując się do koncepcji Robespierre'a i Babeufa, postulowały (nie tylko formalne) wprowadzenie w życie zasad równości, wolności i braterstwa. Przyjęły tę rewolucyjną tradycję nawet pomimo tego, że utopijny socjalizm francuski ich czasów konsekwentnie stał na stanowisku pacyfistycznym. Oddziaływała na nich przede wszystkim wcześniejsza tradycja francuska: dziedzictwo ekspansywnej Wielkiej Rewolucji oraz niechęci do pacyfizmu. Wizja ta opanowała wyobraźnię polskich socjalistów romantycznych oraz marksistów, powodując, że rewolucyjna bezkompromisowość stała się jedną ze stałych cech polskiego socjalizmu. Potwierdzenie tej tezy odnaleźć można w pismach Kelles-Krauza: „My nie możemy być miłośnikami pokoju na inny sposób, jak działacze Wielkiej Rewolucji Francuskiej, którzy wzywając ochotników do zaciagania się pod sztandary rewolucyjne, pisali w proklamacjach: »Wojna wolności z niewolą - będzie to ostatnia wojna!«" (Kelles-Krauz 1962a, 273). Na początku dwudziestego wieku polskie ugrupowania socjalistyczne liczące na szybki wybuch wojny były wyjątkami wśród partii europejskich. Gdy francuscy socjaliści wystosowywali pacyfistyczne deklaracje, PPS-owcy przygotowywali powstańczą agitację (Tych 1982b, 265). Nie chodziło jednak o toczenie wojen narodowych (imperialistycznych), ale, zgodnie $z$ tezą Włodzimierza Lenina, o wykorzystanie wojny światowej do wywalczenia socjalizmu. Wojna może zostać uznana za postępowa i słuszna, jeśli z „,wojny nacjonalizmów” przekształcona zostanie w internacjonalistyczną walkę klasową (Lenin 1987, 306).

Wracając do chronologicznie pierwszego socjalistycznego pokolenia rewolucjonistów, trzeba zauważyć, że radykalizm Gromad, godny czasów Rewolucji Francuskiej, wynikał z nędzy mas, która nie pozwalała im na stosowanie umiarkowanych działań pośrednich. Sama praca, która miała na celu propagowanie postępowej myśli, nie była wystarczająca, na zmianę trzeba by było czekać wieki. Zdaniem Gromad do szybkiego wprowadzenia nowego ładupotrzebny był terror. Był on jednak tylko środkiem do celu, nie zaś celem samym w sobie: „Nie ma w nas myśli machania w lewo i w prawo, zabijania maczugą dla wprawy w siłę lub wylania na zewnątrz

\footnotetext{
${ }^{7}$ Integralnym wydarzeniem Rewolucji Francuskiej była rewolucja haitańska. Według Žižka przyswojenie rewolucyjnych haseł przez niewolników, którzy „zignorowali wszystkie niewypowiedziane wprost zastrzeżenia, w które obfitowała oświeceniowa ideologia [...]" (Žižek 2011, 193), jest przykładem uniwersalności egalitarnych haseł Rewolucji Francuskiej. Jej ideały znalazły swój prawdziwy sens na Haiti. Gdyby nie rewolucja niewolników, Francja, która zdradziła idee rewolucji, nie mogłaby stanowić wzoru nowoczesnej emancypacji. Rewolucja Francuska nie istniałaby bez Haiti, ale i rewolucja haitańska nie wydarzyłaby się bez francuskich haseł. Według słoweńskiego filozofa trzeba więc „uznać znaczenie rewolucji haitańskiej dla Europy” (Žižek 2011, 207).
} 
zbytecznej w nas siły. Nie jesteśmy terrorystami z imienia - jesteśmy rycerzami poświęcenia [...]” (Temkinowa 1957, 92-93).

Taki sam punkt widzenia prezentowała większość marksistów. Dla Róży Luksemburg terror był akceptowalny tylko wtedy, gdy prowadził do spełnienia celów ostatecznych. Grzegorz Kotlarski zaznacza: „Terror jest w tym przypadku złem koniecznym przypominającym bolesny zabieg chirurgiczny” (cyt. za: Kotlarski 1987, 102-103). KellesKrauz również zastrzegał, że chodzi o „przekształcenie prawne całego społeczeństwa dla dobrego normalnego funkcjonowania [...]”, a nie o „rzeź tyranów” (Kelles-Krauz 1962b, 387).

Mimo wszystko rewolucja niosła za sobą konieczność ofiar i wiedzieli to radykałowie całego dziewiętnastego wieku. W tekstach Gromad zawarto ostrzeżenie, że „krew o tyle płynie, o ile lud oporu znajduje" (cyt. za: Barszczewska-Krupa 1979, 312). W przypadku rewolucji każdy miał określić, czy jest zwolennikiem postępu i walczy o sprawę całej ludzkości, czy jest kontrrewolucjonista, który zostanie zgładzony. Prawdziwa walka likwidowała możliwości jakiegokolwiek kompromisu: „Precz więc z obojętnemi; a do nich odezwijmy się słowy Chrystusa: a kto nie jest z nami, jest przeciwko nam” (Temkinowa 1957b, 93). Kilkadziesiąt lat później tę wizję przyszłości podsumował Kelles-Krauz: „Więc cóż pozostaje? Nic, tylko powstanie jako ultima ratio” (Kelles-Krauz 1962c, 212). „Będzie to prawdziwa wojna domowa, z bitwami, rzeziami i oblężeniami, i która może potrwać kilka tygodni a nawet miesięcy [...]" (Kelles-Krauz 1962c, 249). Tak więc „będzie to coś w rodzaju walki Komuny Paryskiej z wersalczykami - tylko na większą skalę, na licznych punktach danego państwa" (Kelles-Krauz 1962c, 249). W obu przypadkach rewolucja była postrzegana jako krwawa wojna, która prowadzi do całościowej zmiany systemu.

Powodzenie rewolucji (oprócz terroru) zapewniała jedność ruchu i ideologii. Idea komunistyczna miała zmienić rzeczywistość, porwać uciśnionych do walki o lepszy świat. „Chcemy ostateczności, obywatele, chcemy widzieć ludzi z myślą, ale razem z gorąca żądzą sprawdzenia tej myśli” (Temkinowa 1957b, 93). Tę rewolucyjną chęć Gromady wyrażały przede wszystkim przez swoistą religijną epistemologię. Religijność Gromad nie miała charakteru transcendentnego, dlatego wiara (wspólnotowe poznanie rzeczywistości społecznej) pozwalała na aktywne działanie w celu utworzenia „Królestwa Bożego na ziemi”. Zmiana byłaby możliwa dopiero w momencie, gdy owa „myśl” zostałaby zaszczepiona ludowi, wtedy też mógłby pojawić się podmiot rewolucyjny. ,Walka więc poprzedzi naszą władzę. A z tej walki zwycięzcy przed lud stanąwszy piórem równości i braterstwa zakreślimy mu kardynalną istnienia społecznego ideę" (Temkinowa 1957b, 94). Taki stosunek do grupy uciskanej nieuchronnie wiązał się z pewnym paternalizmem: „oświeceni” mieli przekazać prawdę o prawach dziejowych żyjącym w ciemnocie: „Lud czuje, że go boli, nie zna tylko lekarstwa. Tym lekarstwem jest terroryzm myśli [...]” (Temkinowa 1957b, 94). Ten agitacyjnoobiektywistyczny charakter Idei został przejęty przez marksizm. Waryński powiadał: „,..] nie 
organizowaliśmy przewrotu, lecz organizowaliśmy dla przewrotu” (cyt. za: Notkowski 1978, 333).

Według socjalistów z obu nurtów (romantycznego i marksistowskiego) warunkiem sukcesu wojny rewolucyjnej był aktywizm mas. Gromady krytykowały defetyzm doktryny Saint-Simona, która deprecjonowała rolę jednostki przy jednoczesnym podkreśleniu znaczenia praw historycznych. Największą wagę przywiązywały do potrzeby ukształtowania się podmiotu zmian, który uchroniłby ludzkość przed kapitalizmem (Sikora 1974, 85-86). Nie wykluczało to tezy o rewolucyjnym spełnieniu się procesu dziejowego. Według gromadzian oraz marksistów komunizm był zwieńczeniem historii, z zastrzeżeniem, że niezbędną jego składową miał być woluntaryzm mas (jeden z „niezmienników” hipotezy komunistycznej). Widać więc wyraźnie przystawalność obu socjalizmów do ram Idei komunistycznej.

\section{Konkluzja}

Wykorzystując koncepcje Badiou i Žižka, starałem się ukazać ciąłość polskiej dziewiętnastowiecznej myśli socjalistycznej, która wynika ze stałej ontologicznej konstrukcji Idei. Žižek ukazał jej złożoność za pomocą Lacanowskiego schematu WyobrażenioweSymboliczne-Realne. Na poziomie wyobrażeniowym Idea zachowuje ciagłość tradycji ruchów równościowych - marksiści nawiązywali do dorobku socjalistów „utopijnych”, socjaliści romantyczni odwoływali się do filozofów rewolucji francuskiej itd. Na poziomie symbolicznym pojawia się zdaniem Žižka aspekt aktualizacji. Idea przywdziewa tu różne formy, gdyż obiektywne okoliczności gospodarczo-społeczne różnią się w zależności od epoki historycznej. Nie chodzi jednak o tytułowe „zerwanie” - socjaliści pierwszej połowy wieku zauważali kapitalistyczne zmiany, zaś marksiści działali w czasach peryferyjnego, feudalnego kapitalizmu. Cechą wspólną dla obu ugrupowań była absolutyzacja własnych dokonań teoretycznych pomimo licznych nawiązań do osiemnastowiecznych rewolucjonistów socjaliści romantyczni odgradzali od nich swój „dojrzały” wiek dziewiętnasty. Z kolei marksiści nadali socjalistom pejoratywne miano „utopijnych”, podkreślając obiektywizm własnej teorii historii. Wreszcie, na poziomie Realnego Idea wymaga istnienia „komunistycznych niezmiennych”. Zarówno marksiści, jak i socjaliści polistopadowi postulowali zaprowadzenie całkowitej równości, zniesienie własności, terror i wiarę w podmiot rewolucyjny (Žižek 2011b). Wszystkie te aksjomaty omówiłem powyżej jako spoiwa ciągłości myśli polskich socjalistów.

Wyodrębnianie utopijności Gromad jako zarzutu, który miałby udowadniać zerwanie w historii polskiego socjalizmu, wydaje się nieuzasadnione. Sam Marks zdawał sobie sprawę z ciągłości utopijnych celów między pokoleniami socjalistów: 
[...] fantastyczne utopie znikły nie dlatego, że klasa robotnicza zrezygnowała z celu do którego dazżyli ci utopiści, lecz wskutek tego, że znalazła realne środki jego osiagnięcia [...] Ale dwa cele końcowe ruchu proklamowanego przez utopistów [tj. wyzwolenie pracy oraz przekształcenie społeczeństwa - przyp. JK] pozostały celami końcowymi proklamowanymi przez rewolucję paryską i Międzynarodówkę (Marks i Engels 1968, 643).

Mimo wszystko „fantastyczne utopie” miały się w Polsce dobrze przez cały wiek dziewiętnasty. Według kryteriów Mannheima marksiści i romantycy byli utopistami przede wszystkim dlatego, że reprezentowali nowe klasy wchodzące na arenę dziejów (Mannheim 1992, 168) oraz ukierunkowywali ich „transcendentne wobec rzeczywistości wyobrażenia” (Mannheim 1992, 169). Tym samym występowali przeciwko ideologii, która według autora Ideologii $i$ utopii jest ideowa reprezentacją klasy panującej i konstruuje właściwy jej porządek symboliczny. Mało kto pamięta, że polscy marksiści końca dziewiętnastego wieku wychowali się na książce $W$ roku 2000 Edwarda Bellamy’ego, która opowiada o przeniesieniu się w czasie do socjalistycznego Edenu przyszłości (Snyder 2010, 42-43). Książka ta, jak i wiele innych, komasując indywidualne instynkty utopijne, pozwalała na dialektyczny rozwój historii: „Byt rodzi utopie, te z kolei rozsadzają byt, tworząc byt następny” (Mannheim 1992, 165). Utopijność pozwala na negację historycznej „pozytywności” (Wójcik 2014, 54) oraz wyznacza cel walki, co trafnie ujęli gromadzianie:

Towarzystwo nazywa je odległymi celami, Konfederacja [Narodu Polskiego - przyp.

$\mathrm{JK}]$ utopią. A więc odległym jest celem braterstwo i środki jego: wszechwładztwo Ludu, równość i wolność! - Odległym jest celem to właśnie co za cel dla społeczności Bóstwo wytknęło! Utopią jest cnota, poświęcenie! (Świętosławski 1854, 63).

Każda ideologia panująca obiektywizowała swoje własne miejsce historyczne, utopia nazywała wszystko, co nie mieściło się w jej ramach. Trzeba zauważyć, „iż niejedno przywłaszczenie, które własnością również nazywano, upadło przecież i że przeciwnie to co miało żyć w przyszłości, było przed jego wprowadzeniem w życie utopią, marzeniem demagogicznym nazwane [...]” (Temkinowa 1957b, 88). Ten sam „komunistyczny” punkt widzenia przyjmuje w dwudziestym pierwszym wieku Jan Sowa w Ciesź sie późny wnuku:

W zasadzie wszystkie najważniejsze zasady i elementy ustroju, w którym żyjemy i które uważamy za wielkie osiagnięcia współczesności - powszechne prawo wyborcze, prawa człowieka, emancypacja kobiet itp. - pojawiły się po raz pierwszy jako utopijne herezje w radykalny sposób nieprzystające do obowiązującego porządku symbolicznego (Sowa 2008, 438). 
Z powyższych cytatów wynika, że powrót do romantyczno-komunistycznej utopii byłby odpowiedzią na dzisiejszy stan „zakneblowanej wyobraźni”. Według Fredrica Jamesona jest on charakterystyczny dla systemu społecznego, który opiera się na cynizmie: nie potrzebuje już uzasadnienia, gdyż wszystko zostaje w nim sprowadzone do jednego mianownika - pieniądza. Ten, gdy zajmuje centralne miejsce w jaźni ludzkiej, wymusza skupienie się na teraźniejszości, „zarabianie pieniędzy nie jest bowiem żadnym projektem, ale działalnością doraźna” (Jameson 2011, 272). W związku z tym utopijnym i najbardziej niebezpiecznym dla systemu postulatem jest zniesienie pieniądza. To żądanie „otwiera przestrzeń, w którą może wejść utopia [...]” (Jameson 2011, 275). Archaiczny postulat, który był bliski wszystkim wcześniejszym utopiom (również gromadzkim), a dzisiaj jest reaktywowany, wymusza kreatywność w tworzeniu nowych wizji, domaga się spojrzenia w przyszłość jako możliwość. W wyniku przyjęcia tego założenia współczesne utopie antykapitalistyczne nieuchronnie będą musiały zachować ciagłość z wcześniejszymi fantazjami. Jameson podkreśla, że obalenie eterycznej władzy pieniądza nie jest łatwym zadaniem, ponieważ współczesne problemy społeczne uwidaczniają się w wizjach dystopijnych (np. końca świata) zamiast, tak jak kiedyś, w wyobrażeniach utopijnych. Według autora by stawić czoło temu problemowi, należy „przejść od analizy kapitalizmu i jego ideologii do analizy strachu przed utopią” (Jameson 2016, 54). „Utopijne myślenie musi zawierać przede wszystkim radykalna terapię dystopii, jej leczenie i wyleczenie" (Jameson 2016, 54). Dopiero po tym zabiegu możliwe będzie wykorzystanie utopii jako narzędzia politycznego, tak dzisiaj potężnego ze względu na to, że „potrząsając łańcuchami, osiagamy stan intensywnej koncentracji duchowej, przygotowując się na kolejny etap, który jeszcze nie nadszedł" (Jameson 2011, 276).

Powrót do polskiej utopii romantycznej może stanowić właśnie taką „terapię". Przywołanie wizji gromadzian, w których jednostkowość ginie niczym w realiach stalinowskich, pomogłoby w przepracowaniu socjalistycznych porażek i w wypracowaniu na tej podstawie nowego programu. Słowami Žižka: chodziłoby o „powtórzenie początku po raz kolejny” (Žižek 2011a, 148).

Czy jednak jedynym powodem reaktywacji romantycznego idealizmu powinna być chęć przezwyciężenia kapitalistycznej anemii wyobraźni? Dlaczego nie można nadal polegać na ortodoksyjnej marksistowskiej utopii konieczności historycznej? Leninizująca interpretacja marksizmu ${ }^{8}$ stała się w Polsce powojennej ideologią legitymizująca i uzasadniająca system polityczny PRL. Marksizm-leninizm siłą rzeczy stał się politycznie zachowawczy: musiał udowodnić słuszność swego miejsca historycznego, potwierdzać rzeczywistość, nie zaś tworzyć utopijne wizje podważające ja. Ujmując sprawę w kategoriach Mannheima, można powiedzieć,

\footnotetext{
${ }^{8}$ Chodzi tu o taką wykładnie marksizmu, która potwierdza biurokratyczny system władzy. Lenin powiedział kiedyś: „socjalizm znaczy ewidencja” (cyt. za: Kołakowski 2009, 500). Mowa więc o ideologii, która prezentuje jedyną właściwą eksplikację zjawisk społecznych, ograniczając tym samym możliwość opozycji wobec systemu.
} 
że socjalizm z utopii przekształcił się w ideologię? (chociaż według węgierskiego socjologa nie da się ich całkowicie rozdzielić - znajdują się bowiem w dialektycznym związku). Zygmunt Bauman wyciagnął z tego ważki wniosek:

[...] jakąkolwiek moc inspirującą socjalizm by posiadał, czerpie on ją właśnie ze swego utopijnego statusu. Jest przyrodzoną przywarą socjalizmu [...], że pozostaje on historycznie płodny tak długo tylko, jak przebywa w strefie możliwości. Traci swoja moc twórczą, gdy ogłasza się go osiagniętym [...] (Bauman 2010, 39-40).

Daje to dziś następny powód do aktualizacji utopii: przezwyciężenie konserwatywnej interpretacji marksizmu. Tę potrzebę powrotu do socjalizmu jako możliwości w czasach, w których nie istnieja już „socjalizmy osiagnięte” (państwowe), wyraża Jan Sowa:

Gdyby historyczny determinizm był prawdą, moglibyśmy spokojnie siedzieć i czekać, aż kapitalizm wywróci się pod naporem własnych wewnętrznych sprzeczności, a z jego ruin spontanicznie zrodzi się lepszy świat. Nie wierzę, aby tak było [...].Jeśli z kryzysu ma zrodzić się coś lepszego, będzie to tylko to, co wymyślimy (Sowa 2008, 29).

Według Sowy ożywienie utopii nie polegałoby na powrocie do konkretnych, archaicznych wyobrażeń przyszłości (które z pewnością dzisiaj nazwalibyśmy totalitarnymi), ale z powrotem do tworzenia utopii w ogóle. Zwykle wiąże się z tym postulat rehabilitacji jakiejś formy politycznego idealizmu. Opisywany w tym artykule marksizm „pokolenia niepokornych” (końca dziewiętnastego wieku) był właśnie taką wielką restytucją romantyzmu oraz apoteozy czynu. Podobnie jak GLP, a współcześnie Jameson czy Sowa niepokorni krytykowali materializm oraz cynizm społeczeństwa opartego na pieniądzu. Dla polskich marksistów jego symbolem ideowym w drugiej połowie dziewiętnastego wieku stał się pozytywizm. Według Bohdana Cywińskiego socjaliści byli elementem wywrotowym w tym czasie ,zmaterializowania i bezideowości" (Cywiński 2010, 19). Wywołali reakcję przeciwko pozytywistycznemu defetyzmowi, nie odrzucili jednak całkowicie pozytywistycznych ideałów. Jak wskazuje PorterSzűcs, „[n]iepokorni nie tyle byli antypozytywistyczni, co postpozytywistyczni” (Porter-Szűcs 2011, 134). Doprowadzili do syntezy „wielkich ideałów” z naukowymi dokonaniami

\footnotetext{
${ }^{9}$ Socjolog przedstawia ten schemat na przykładzie klasy mieszczańskiej. Jako klasa rewolucyjna, która występowała przeciwko feudalizmowi, opierała się ona na własnych wyobrażeniach utopijnych (np. wolności), jednak po zdobyciu władzy w jej liberalnym dyskursie przeważać zaczęły elementy ideologiczne. Burżuazyjna utopijność opierała się na dwóch filarach: podważeniu starego układu społecznego oraz częściowemu urzeczywistnieniu swoich postulatów (Mannheim 1992, 168). Te dwie własności stanowią o głównej różnicy między ideologią a utopią: „Idee, co do których okazało się później, że unosiły się jedynie nad istniejącym lub rozwijającym się porządkiem życia jako wyobrażenia maskujące, były ideologiami; to co zostało z nich adekwatnie urzeczywistnione w następnym etapie rzeczywistości [podkr.- JK], było względną utopią" (Mannheim 1992, 169).
} 
wcześniejszej epoki. Połączyli realizm z idealizmem politycznym. Jeśli przyjmiemy, że pozytywizm otwierał epokę nowoczesności, to dzisiaj myślenie utopijne (np. zaprezentowane przez Jamesona w An American Utopia) nie jest antynowoczesne, ale postnowoczesne. Powrót do romantycznej utopii nie byłby prostym naśladownictwem archaicznych wyobrażeń, ale ich zintegrowaniem z dokonaniami nowoczesności. Wymagałby Jamesonowskiego „terapeutycznego” wyleczenia strachu przed dawną utopią i dystopią. Byłby więc aktualizacją Idei komunistycznej, która zachowałaby ciagłość z utopiami socjalistów polistopadowych oraz z polską utopią marksistowska. Taki uniwersalnie romantyczny charakter ponownego „wynalezienia” Idei komunistycznej silnie wybrzmiewa w pismach Badiou. Według francuskiego filozofa utopijne myślenie stanowi o człowieczeństwie i to przede wszystkim o nie toczy się dzisiaj walka:

Człowiek jako nieśmiertelny wspiera się na tym co nieobliczalne i nieposiadalne. Wspiera się na tym co nieistniejące. Próba pozbawienia go prawa do przedstawiania jakiejś wizji Dobra, do podporządkowania temu swych sił zbiorowych, do pracy na rzecz nieoczekiwanego urzeczywistnienia nowych możliwości, do myślenia tego, co może zaistnieć w oderwaniu od tego, co jest, oznacza pozbawienie go po prostu jego człowieczeństwa (Badiou 2009, 33).

Podziękowania: Autor pragnie podziękować redakcji Praktyki Teoretycənej, przede wszystkim Piotrowi Kuligowskiemu oraz Bartoszowi Wójcikowi, za cenne uwagi krytyczne dotyczące pierwotnej wersji artykułu, a także doktorowi Krzysztofowi Świrkowi i nieocenionej Joannie Piechurze za pouczającą dyskusję. 


\section{Wykaz literatury}

Badiou, Alain. 2008. The Meaning of Sarcozy. Tłum. David Fernbach. London-New York: Verso.

Badiou, Alain. 2009. Etyka: Przewodnik Krytyki Politycznej. Tłum. Paweł Mościcki. Warszawa: Wydawnictwo Krytyki Politycznej.

Badiou, Alain. 2010. The Communist Hypothesis. Tłum. David Macey i Steve Corcoran. London-New York: Verso.

Badiou, Alain. 2015. Manifesty dla filozofii. Tłum. Andrzej Wasilewski. Warszawa: PWN.

Barszczewska-Krupa, Alina. 1979. Reforma czy rewolucja: Koncepcje przeksztatcenia społeczeństwa polskiego w myśli politycznej Wielkiej Emigracji: 1832-1863. Łódź: Wydawnictwo Lódzkie.

Bauman, Zygmunt. 2010. Socjalizm: Utopia w driałaniu. Tłum. Michał Bogdan. Warszawa: Wydawnictwo Krytyki Politycznej.

Bosteels, Bruno. 2011. Badiou and Politics. Durham-London: Duke University Press.

Brock, Peter. 1954. "Zeno Świętosławski, a Polish Forerunner of the Narodniki”. The American Slavic and East European Review 4: 566-587.

Brock, Peter. 1958. Z driejów Wielkiej Emigracji w Anglii. Tłum. Antoni Ślósarczyk. Warszawa: Książka i Wiedza.

Burawoy, Michael. 1985. The Politics of Production: Factory Regimes Under Capitalism and Socialism. London: Verso.

Ciołkosz, Adam i Lidia Ciołkosz. 1966. Zarys driejón socjalizmu polskiego. T. I. Londyn: Gryf Publications LTD.

Cywiński, Bohdan. 2010. Rodowody niepokornych. Warszawa: PWN.

Czekaj, Katarzyna. 2008. „Rozłam w Polskiej Partii Socjalistycznej w oświetleniu publicystów »Trybuny«". Acta Universitatis Lodziensis. Folia Historica 83: 102-124.

Dyksztajn, Szymon. 1904. „Dążenia socyalistyczne na emigracyi polskiej 1831 roku”. W Witold Jodko-Narkiewicz i Szymon Dyksztajn. Polski socyalizm utopijny na emigracyi (dwie roaprany). Kraków: Nakładem Spółki Nakładowej „Książka”.

Fromm, Erich. 2017. Zdrowe Społeczeństwo. Tłum. Anna Tanalska-Dulęba. Kraków: Wydawnictwo Vis-à-vis Etiuda.

Galbraith, John K. 1973. Spoteczeństwo dobrobytu-państwo przemystowe. Tłum. Jerzy Prokopiuk i Zofia Zinserling. Warszawa: PIW.

Jameson, Fredric. 2011. Archeologie praysz̨łości: Pragnienie z̧wane utopiq i inne fantazje naukowe. Tłum. Maciej Płaza, Małgorzata Frankiewicz i Andrzej Miszk. Kraków: Wydawnictwo UJ.

Jameson, Fredric. 2016. An American Utopia. W Fredric Jameson. American Utopia: Dual Power and the Universal Army, red. Slavoj Zizek. London: Verso.

Kalembka, Sławomir. 2003. Wielka Emigracja 1831-1863. Toruń: Wydawnictwo Adam Marszałek.

Kelles-Krauz, Kazimierz. 1962a. „Socjalizm a pokój europejski”. W Kazimierz Kelles-Krauz. Pisma wybrane. Tom II. Warszawa: Książka i Wiedza.

Kelles-Krauz, Kazimierz. 1962b. „Niepodległość Polski a materialistyczne pojmowanie dziejów”. W Kazimierz Kelles-Krauz. Pisma wybrane. Tom II. Warszawa: Książka i Wiedza. 
Kelles-Krauz, Kazimierz. 1962c. „Nasz kryzys”. W Kazimierz Kelles-Krauz. Pisma wybrane. Tom II. Warszawa: Ksiazżka i Wiedza.

Koberdowa, Irena. 1977. Poczatki polskiej myśli socjalistycznej do powstania zorganizowanego ruchu robotnicæego. Warszawa: Wyższa szkoła nauk społecznych przy KC PZPR, Instytut Ruchu Robotniczego.

Koberdowa, Irena. 1989. Polska rewolucyjna myśl społeczna na tle myśli europejskiej w połowie XIX wieku. W Józef Kulas (red.). Gromady Ludu Polskiego. Materiaty z sesji naukowej. Warszawa: Akademia Nauk Społecznych PZPR.

Kołakowski, Leszek. 2009. Główne nurty marksizmu, tom 2. Warszawa: PWN.

Kotlarski, Grzegorz. 1987. Myśl społeczna Róży Luksemburg: próba rekonstrukcji bistoriozofii. Poznań: Wydawnictwo Naukowe UAM.

Kula, Witold. 1983. Historia, zacofanie, rozwój. Warszawa: Czytelnik.

Kuligowski, Piotr. 2012. „Miecz Chrystusa. Chrześcijańskie inspiracje polskiego socjalizmu sprzed powstania styczniowego". Ogrody nauk i sqtuk 2: 50-61.

Kuligowski, Piotr. 2015. „Remarks on Communes of the Polish People: the Character of Organization, the Ideology, the Meaning". Journal of Education, Culture and Society 2: 268282.

Lenin, Włodzimierz. 1985. „Socjalizm a chłopstwo”. W Włodzimierz Lenin. Drieła wszystkie, tom 11. Warszawa: Książka i Wiedza.

Lenin, Włodzimierz. 1987. „Socjalizm a wojna (stosunek SDPRR do wojny)”.

W Włodzimierz Lenin. Dqieła wszystkie, tom 26. Warszawa: Książka i Wiedza.

Limanowski, Bolesław. 1948. Stanisław Worcell: Życiorys. Warszawa: Spółdzielnia Wydawnicza „Wiedza”.

Łepkowski, Tadeusz. 1967. Polska - narodziny nowoczesnego narodu 1764-1870. Warszawa: PWN. Mannheim, Karl. 1992. Ideologia i utopia. Tłum. Jan Miziński. Lublin: Wydawnictwo „Test”.

Marchlewicz, Krzysztof. 2008. Wielka Emigracja na Wyspach Brytyjskich (1831-1863). Poznań: Wydawnictwo PTPN.

Marks, Karol i Fryderyk Engels. 1968. „Pierwszy szkic »Wojny domowej we Francji«”. W Karol Marks i Fryderyk Engels. Drieła, tom 17. Warszawa: Książka i Wiedza.

Marks, Karol i Fryderyk Engels. 1983. Manifest Komunistyczny. Wstęp: Irena Koberdowa. Warszawa: Książka i Wiedza.

Mencwel, Andrzej. 2013. Kaz̧imierz Kelles-Krauæ: Przysz̧łośćpržesz̨ości. W Grzegorz Godlewski, Andrzej Kołakowski, Joanna Kubicka, Paweł Majewski, Andrzej Mencwel, Paweł Rodak i Małgorzata Szpakowska (red.). Kulturologia polska XX wieku. Warszawa: Wydawnictwa UW.

Najdowski, Zygmunt. 1989. „Problem utopijności Gromad Ludu Polskiego w świetle oświeceniowej i romantycznej wizji sprawiedliwości społecznej”. W Józef Kulas (red.). Gromady Ludu Polskiego. Materiaty z sesji nankowej. Warszawa: Akademia Nauk Społecznych PZPR.

Notkowski, Andrzej. 1976. Ludwik Waryński. Wrocław i in.: Zakład Narodowy im. Ossolińskich.

„Odezwa Komitetu Robotniczego Soc. Rew. »Proletariat«”. 1975. W Feliks Tych (red.). Polskie programy socjalistyczne 1878-1918. Warszawa: Książka i Wiedza.

Okólniki Towarzystwa Demokratycznego Polskiego 1834/1836. Sygn. Cz1161; Sygn. Cz2104. Biblioteka Kórnicka Polskiej Akademii Nauk. 
Porter-Szűcs, Brian. 2011. Gdy nacjonalizm zaczq̨ nienawidzić: Wyobrażenia nowoczesnej polityki w driewiętnastowiecznej Polsce. Tłum. Agnieszka Nowakowska. Sejny: Pogranicze.

Sikora, Adam. 1974. Gromady Ludu Polskiego. Warszawa: Wiedza Powszechna.

Snyder, Timothy. 2010. Nacjonalizm, marksižm i nowoczesna Europa Środkowa: Biografia Kazimierza Kelles-Krauza (1872-1905). Warszawa: Wydawnictwo Krytyki Politycznej.

Sowa, Jan. 2008. Ciesz siępóźny wnuku! Kolonialižm, globalizacja i demokracja radykalna. Kraków: Korporacja Ha!art.

Sowa, Jan. 2011. Fantomowe ciało króla: Peryferyjne żmagania z. nowoczesna forma. Kraków: Universitas.

Szpotański, Stanisław. 1907. Lud Polski (z driejón polskiej myśli socyalistycznej). Lwów: Polskie Towarzystwo Nakładowe.

Świętosławski, Zenon (red). 1854. Lud Polski w emigracji 1835-1846. Jersey: Druk. Powszechna.

Temkinowa, Hanna. 1955. Socjalizm utopijny Gromad Ludu Polskiego. Warszawa: Polska Akademia Nauk, Sekcja Historii i Historii Filozofii.

Temkinowa, Hanna. 1957a. „Wstęp”. W Hanna Temkinowa (red.). Lud Polski: Wybór dokumentów. Warszawa: Książka i Wiedza.

Temkinowa, Hanna (red.). 1957b. Lud Polski: wybór dokumentów. Warszawa: Książka i Wiedza.

Temkinowa, Hanna. 1962. Gromady Ludu Polskiego (zarys ideologii). Warszawa: Książka i Wiedza.Tych, Feliks. 1982a. Socjalistyczna irredenta: Szkice z. driejów polskiego ruchu robotniczego pod zaborami. Kraków: Wydawnictwo Literackie.

Tych, Feliks. 1982b. „Druga Międzynarodówka (1889-1914) wobec kwestii narodowej”. Kwartalnik Historyczny 89. 2/3: 251-270.

Wójcik, Bartosz. 2014. „Dialektyka utopii”. Estetyka i Krytyka 35: 49-72.

Žižek, Slavoj. 2008. W obronie przegranych spraw. Tłum. Julian Kutyła. Warszawa: Wydawnictwo Krytyki Politycznej.

Žižek, Slavoj. 2011a. Od tragedii do farsy, csyli jak historia sie powtarza. Tłum. Maciej Kropiwnicki i Barbara Szelewa. Warszawa: Wydawnictwo Krytyki Politycznej.

Žižek, Slavoj. 2011b. „Why the Idea and Why Communism?”. http://lacan.com/symptom12/why-the.html. 
Jan Kozubowski - student Kolegium Międzywydziałowych Indywidualnych Studiów Humanistycznych UW. Interesuje się historia polskiego marksizmu dziewiętnastowiecznego, ze szczególnym naciskiem na socjologiczne dokonania Kazimierza Kelles-Krauza oraz jego polemikę z poglądami Róży Luksemburg na temat niepodległości Polski.

\section{DANE ADRESOWE:}

Kolegium MISH

Uniwersytet Warszawski

Prosta 69

00-838 Warszawa

EMAIL: kozubowskijan@gmail.com

Cytowanie: Kozubowski, Jan. 2018. „Ciąłość czy zerwanie? Przyczynek do rozważań na temat historii polskiej myśli socjalistycznej dziewiętnastego wieku". Praktyka Teoretycz̨na 3(29): $51-77$.

DOI: $10.14746 /$ prt.2018.3.3

AUTHOR: Jan Kozubowski

TitLE: Continuity or Rupture? Reflections on the History of 19th Century Polish Socialist Thought

ABSTRACT: The aim of the article is to subvert the division of Polish socialism into "scientific socialism" and "utopian socialism," which was a widely held approach in Polish historiography after WWII. Alain Badiou's and Slavoj Žižek's concepts of "the idea of communism" are applied to Polish Socialist thought to stress the fact of its ideological continuity. "The idea of communism" allows for a critique of Polish communist historians, who advocated the aforementioned divisive methodology. A comparison of Marxist concepts to the ideology of the 'Communes of the Polish People' demonstrates that their differences are determined by the historic nature of the socio-economic environment and serves to distinguish a specific set of Polish "communist invariants."

KEYwORDS: scientific socialism, utopian socialism, Communes of the Polish People, utopianism, Marxism, Kazimierz Kelles-Krauz 